\title{
PENGELOLAAN PERBATASAN SEBAGAI GARDA TERDEPAN KEDAULATAN
}

\author{
Shinto ${ }^{1}$
}

\begin{abstract}
Abstrak: Sebagai negara maritim diperlukan tata kelola daerah perbatasan terutama pulau terluar dengan pengelolaan yang baik, terstruktur dan terencana. Diperlukan kerjasama dan sinergi dari beberapa institusiyang tercantum dalam Peraturan Presiden Nomor 12 Tahun 2010 agar dapat mencapai tujuan tersebut. Tata kelola perbatasan yang baik berdampak sangat penting bagi pertumbuhan perekonomian suatu daerah, sehingga dapat mengurangi ketergantungan terhadap negara tetangga. Jika kemandirian ekonomi dan kesejahteraan tercapai, kemudahan fasilitas, lengkapnya sarana dan prasarana yang tersedia, maka aspek fisik, psikologis, keamanan dan sosial budaya akan dapat menciptakan suatu benteng pertahanan bagi Kedaulatan Negara Kesatuan Republik Indonesia.
\end{abstract}

Kata Kunci : perbatasan, pertahanan, kemandirian, keamanan, kedaulatan

\section{PENDAHULUAN}

Indonesia yang memiliki13.466 2 pulau besar dan kecil, dan sekitar 6.000 di antaranya tidak berpenghuni, mempunyai luas daratan sebesar $1.922 .570 \mathrm{~km}^{2}$ dengan luas perairan $3.257 .483 \mathrm{~km}^{2}$, merupakan negara Kepulauan terbesar di Dunia. Sebagian besar wilayahnya berupa lautan maka dapat dikatakan juga bahwa Indonesia merupakan negara Maritim. Untuk menjaga kedaulatan dan melindungi kekayaan atas kepulauan serta laut yang terkandung didalamnya, maka pada tahun 1957 Indonesia mendeklarasikan Deklarasi Juanda dan pada akhirnya PBB membuat konvensi tentang Hukum Laut (UNCLOS) 1958, dan dalam pengembangannya menghasilkan UNCLOS 1982 yang telah diratifikasi oleh 159 Negara. Sebagai negara maritim, yang memiliki gugusan kepulauan di sepanjang perbatasan dengan negara tetangga, maka diperlukan pengelolaan yang serius untuk menjaga kedaulatan atas pulau-pulau terluar dan kekayaan laut yang terkandung didalamnya. Keseriusan tersebut terwujud dalam Undang-Undang No. 43 Tahun 2008 tentang Wilayah Negara, dan sebagai pengejawantahan atas Undang-Undang tersebut maka

\footnotetext{
${ }^{1}$ Penulis merupakan anggota Lembaga KERIS yang dapat dihubungi melalui email : shinto.axl@gmail.com

2 Jumlah pulau menurut rilis Bakosurtanal tahun 2014, Informasi tersebut ini dikatakan Kepala Badan Informasi Geospasial Asep Karsidi kepada Menteri Pariwisata dan Ekonomi Kreatif Mari Elka Pangestu, saat serah terima perangkat pendukung infrastruktur informasi geospasial di Gedung Sapta Pesona Kemenparekraf Jakarta, pada 7 Mei 2014
}

lahirlah Peraturan Presiden Nomor 12 Tahun 2010 dengan membentuk Badan Nasional Pengelola Perbatasan (BNPP).

\section{PENGELOLALAAN PERBATASAN} Indonesia dengan kondisi geografis negara kepulauan, mempunyai perbatasan darat dengan tiga negara tetangga, yaitu Malaysia, Papua Nugini dan Timor Leste. Sementara perbatasan laut dengan sepuluh negara tetangga, diantaranya Malaysia, Singapura, Vietnam, Filipina, Papua Nugini, Timor Leste, India, Thailand, Australia, dan Palau. Hal ini tentunya sangat erat kaitannya dengan masalah penegakan kedaulatan dan hukum di laut, pengelolaan sumber daya alam serta pengembangan ekonomi kelautan suatu negara. Kompleksitas permasalah di laut akan semakin memanas akibat semakin maraknya kegiatan di laut, seperti kegiatan pengiriman barang antar negara yang 90\%nya dilakukan dari laut, ditambah lagi dengan isu-isu perbatasan, keamanan, kegiatan ekonomi dan sebagainya.Dapat dibayangkan bahwa penentuan batas laut menjadi sangat penting bagi Indonesia, karena sebagian besar wilayahnya berbatasan langsung dengan negara tetangga di wilayah laut atas laut teritorial diukur berdasarkan garis pangkal yang menghubungkan titik-titik dasar yang terletak di pantai terluar dari pulau-pulau terluar wilayah NKRI. Berdasarkan hasil survei base point atau titik dasar untuk menetapkan batas wilayah dengan negara tetangga, terdapat 
183 titik dasar yang terletak di 92 pulau terluar, sisanya ada di tanjung tanjung terluar dan di wilayah pantai.

Pulau-pulau terluar yang biasanya merupakan daerah terpencil dan jauh dari jangkauan pemerintah pusat, cenderung menjadi daerah miskin dan terbelakang dikarenakan kurangnya perhatian dari pemerintah pusat. Kondisi tersebut sangat membahayakan jika tidak ada penanganan yang serius dari Pemerintah yang dapat mengakibatkan hilangnya pulau tersebut. Adapun ancaman hilangnya pulau bisa terbagi menjadi 3 kategori, yaitu ${ }^{3}$ :

1. Hilang secara Fisik, yaitu hilangnya pulau dikarenakan kondisi alam, baik itu dikarenakan abrasi dari air laut maupun karena faktor air pasang.

2 Hilang secara Kepemilikan, yaitu hilangnya status kepemilikan pulau dikarenakan adanya penguasaan oleh individu maupun negara baik melalui pembelian, kekuatan militer maupun hasil keputusan hukum internasional atas kepemilikan suatu pulau, contohnya pulau Sipadan dan Ligitan.

3 Hilang secara sosial dan ekonomi, yaitu sebagai akibat kondisi sosial dan ekonomi yang terjadi dikepulauan tersebut, bisa terjadi dikarenakan perdagangan, ataupun faktor historis penduduk yang mendiami kepulauan tersebut secara turun-temurun.

Untuk mengantisipasi hal tersebut, maka Pemerintah pada tahun 2010 telah menetapkan Peraturan Presiden Nomor 12 Tahun 2010 dengan membentuk Badan Nasional Pengelola Perbatasan (BNPP) sesuai amanah dari UndangUndang No. 43 Tahun 2008. BNPP dengan keanggotaan 18 Kementrian/ Lembaga Pemerintah non Kementrian serta 12 Gubernur di kawasan perbatasan diharapkan dapat menjawab pengelolaan batas wilayah serta mendorong pembangunan kawasan perbatasan secara terintregasi dan terpadu. Walau cakupan masih luas, akan tetapi diharapkan fokus kedepan lebih menitikberatkan terhadap pulau-pulau

\footnotetext{
${ }^{3}$ Lalu Muhamad Jaelani, Teknik Geodesi Fakultas Teknik Sipil dan Perencanaan, ITS, Sukolilo, Surabaya, 60111
}

terluar. Pembentukan Badan Pengelola Perbatasan tersebut diharapkan bisa menjadi jalan keluar dari berbagai permasalahan mengenai perbatasan, baik itu perbatasan darat maupun perbatasan di perairan dan pulau terluar. Perbatasan yang selama ini diidentikan sebagai daerah yang tak terurus, terbelakang dan hanya sebagai simbol politis harus segera dibenahi, pembenahan ini diharapkan akan mempengaruhi juga terhadap taraf hidup masyarakat dan juga faktor pertahanan. Oleh karena itu diharapkan pemerintah daerah yang paling berperan harus proaktif guna mewujudkan tujuan tersebut.

\subsection{Kerjasama dan Sinergi antar Instansi}

Walaupun sudah dibentuk Lembaga Pemerintah yang khusus menangani masalah perbatasan, yaitu Badan Pengelolaan Perbatasan (BNPP) dengan keanggotaan 18 instansi, tapi dalam implementasi dilapangan masih belum bisa bekerja secara maksimal, dikarenakan Badan Nasional Pengelola Kawasan Perbatasan yang dibentuk Pemerintah belum cukup memadai karena sifatnya lebih merupakan badan koordinasi kebijakan yang tidak memiliki wewenang komando terhadap masyarakat, wilayah maupun institusi politik di daerah. Agar semua dapat bekerja maksimal maka diperlukan kerjasama dan sinergi antar instansi terkait.

Era otonomi daerah memberikan keleluasaan bagi pemerintah daerah untuk bisa mengelola setiap jengkal daerahnya untuk menghasilkan nilai tambah bagi pendapatan daerah dengan cara memanfaatkan sumber daya yang ada. Agar pengelolaan bisa maksimal serta adanya keterbatasan sarana dan prasarana yang dimiliki setiap pemerintah daerah, maka diperlukan kerjasama dengan instansi lain yang mungkin bersinggungan langsung, dalam hal ini salah satu contohnya adalah institusi TNI, pemilihan TNI khususnya TNI AL sebagai pihak yg perlu diajak kerjasama bukan tanpa alasan, yaitu :

a. Merupakan institusi yang salah satu tupoksinya adalah 
mengamankan

perbatasan ${ }^{4}$.

b. Mempunyai sumber daya dan prasarana yang mendukung, yaitu personel lengkap, Alutsistayang memadai terutama kapal laut yang dapat diperbantukan guna pengelolaan, membantu kemudahan logistik serta pengamanan perbatasan.

c. Memberikan rasa aman dan perlindungan terhadap penduduk yang menempati pulau perbatasan tersebut dari ancaman dan gangguan kedaulatan terutama dari negara tetangga.

d. Memberikan identitas dan penegasan atas kedaulatan.

e. Dibantu instansi yang lain dapat berfungsi sebagai Penegakan hukum terhadap pelanggaran hukum di laut dan pulau-pulau terluar perbatasan (penyelundupan, pencurian ikan, penambangan pasir laut ilegal, serta kejahatan di perbatasan laut lainnya).

Sebagai salah satu perwujudannya bisa dilakukan melalui perjanjian kerjasama (agreement) antara pemerintah daerah dengan institusi TNI dalam hal ini TNI AL. Salah satu kerjasama yang mungkin sangat diperlukan yaitu bantuan untukmengangkut logistik dan kebutuhan bahan pokok untuk masyarakat kepulauan tersebut, terutama bagi pulau yang kebutuhan pokoknya sangat bergantung dari pasokan negara tetangga yang berbatasan langsung. Jikasegala kebutuhan pokok dapat didapat dengan mudah dengan harga yang tidak berbeda jauh dari negara tetangga, maka tingkat ketergantungan akan menjadi berkurang, sehingga kecil kemungkinan muncul ceritabahwa warga pulau berniat pindah kewarganegaraan dikarenakan imingiming kehidupan dan sarana-prasarana yang lebih baik di daerah seberang.

\footnotetext{
${ }^{4}$ Poin no. 4 dari 14 poin Tugas Pokok TNI dalam operasi militer selain perang
}

\subsection{Faktor ekonomi bagi pengembangan dan pembangunan pulau-pulau terluar}

Seperti kita ketahui bahwa 90\% transaksi perekonomian, khususnya perdagangan di daerah-daerah terpencil berasal dari di lautan, untuk itu diperlukan biaya yang besar untuk melakukan transaksi perpindahan barang/jasa agar sampai di masyarakat. Kitamengetahui pula transportasi melalui laut memerlukan waktu yang relatif lama untuk membawa suatu barang hingga sampai ke tempat tujuan. Kondisi tersebut sangat berpengaruh terhadap tingkat pembangunan dan pengembangan perekonomian suatu pulau. Dapat kita ambil contoh seperti kebutuhan pokok masyarakat, yaitu minyak goreng atau gula:

a. Harga Minyak Goreng di pusat pemerintahan terdekat Rp. 10.000,-/L, Harga Gula pasir Rp. $10.000,-/ k g$, sedangkan harga minyak goreng di pulau terdekat (negara tetangga) asumsi Rp. $11.000,-/ L$ dan gula pasir Rp. $12.000,-/ \mathrm{kg}$.

b. Ongkos angkut rata-rata dari pusat pemerintahan yaitu $R p$. $1.000,-/ \mathrm{kg}$, dan ongkos angkut rata-rata dari pulau terdekat yaitu Rp, 500,-'kg (ongkos angkut dari pusat pemerintahan lebih mahal dikarenakan terkendala jarak dan sarana prasarana yang terbatas).

c. Jika kita membuat perbandingan harga sampai di konsumen adalah: Minyak Goreng $=R p$. 500,- selisih lebih murah dibanding beli dari pulau terdekat. Gula Pasir = Rp. 1.500,selisih lebih murah dibanding beli dari pulau terdekat.

Akan tetapi, hitung-hitungan secara matematika tersebut akan sangat berbeda dengan praktik di lapangan, hal itu dapat terjadi dikarenakan beberapa faktor yang berpengaruh, misalnya waktu dan kemudahan dalam memeperoleh produk tersebut. Jika kita membeli dari pusat pemerintahan memakan waktu yg lebih lama dikarenakan jarak, maka akan sangat berpengaruh terhadap 
ketersediaan dan kualitas produk selama pengangkutan, lain halnya jika membeli dari pulau terdekat, walaupun harganya lebih mahal, tingkat ketersediaan produk dan kualitas produk bisa lebih terjamin karena mudahnya akses untuk mendapatkan barang tersebut. Dengan pembangunan sarana dan prasarana yang baik, peran serta pemerintah daerah dan bantuan dari instansi terkait dalam hal ini TNI AL mutlak diperlukan agar dapat berjalan dengan baik. Dengan begitu akan memotong siklus perputaran barang dan jasa yang sangat tergantung dengan negara tetangga. Perputaran barang dan jasa memiliki implikasi terhadap perekonomian nasional terutama uang valas sebagai alat tukar menukar yang sah, semakin sedikit kita membeli barang dari negara tetangga, maka akan membawa dampak yang positif terhadap nilai tukar Rupiah terhadap mata uang asing, terutama negara tetangga.

Dilihat dari gambaran diatas dapat kita tarik kesimpulan bahwa, faktor perekonomian memiliki berpengaruh yang besar terhadap kehidupan sosial kemasyarakatan. Jika pulaupulau yang terpencil dikelola dengan baik, fasilitas terpenuhi, akses barang mudah serta dikelola layaknya halaman rumah sendiri, termasuk membangun fasilitas untuk publik seperti sarana ibadah, sekolah dan pasar, memberikan akses informasi dan komunikasi yang memadai, seperti aliran listrik, siaran televisi dan BTS seluler, maka dapat diartikan bahwa pemerintah sudah memberi perhatian serius terhadap batas kedaulatan, sehingga masyarakat diperbatasanpun merasa selalu diayomi dan dihargai sebagai sebuah warga negara. Kondisi tersebut membawa dampak psikologis terhadap warga negara, sehingga merasa memiliki dan menjaga wilayahnya, terutama dari ancaman sosial dan budaya dari negara tetangga.

\subsection{Benteng dari Ancaman Kedaulatan}

Pulau perbatasan yang dikelola dengan baik, baik itu manusia dan sumberdaya yang terkandung didalamnya, merupakan benteng tangguh terhadap segala bentuk ancaman dari negara tetangga. Pengelolaan yang terencana dan terstruktur diharapkan mampu membuat pulau-pulau di perbatasan siap untuk membentengi diri dari pengaruh dan ancaman yang mulai berkembang saat ini, baik itu nelayan-nelayan dari Philipina dan Thailand, juga gencarnya kekuatan ekspansif dari China yang mulai mengarah ke area Laut China Selatan.

Aspek yang dapat ditimbulkan oleh adanya tata kelola perbatasan yang baik, meliputi beberapa hal, yaitu :

\section{Aspek Fisik}

Pulau perbatasan yang telah terkelola dengan baik, akan menunjukkan indentitas fisik atas kepemilikan dan kedaulatan suatu negara, sehingga negara tetangga akan berpikir ulang untuk melakukan tindakan perongrongan atas suatu daerah / area yang terdapat di sekitar kawasan teritorial. Salah satu contohnya adalah kasus Pulau Sipadan dan Ligitan yang terjadi dikarenakan kurangnya bukti fisik atas kepemilikan serta keteledoran pemerintah dalam pengelolaan kedua pulau tersebut yang akhirnya berakibat Indonesia menyerahkan dengan berat hati ke negara tetangga setelah kalah dalam pengadilan Arbitrase Internasional. Hal ini merupakansuatu pelajaran yang harus dibayar mahal, karena bukan saja kita kehilangan dua pulau, akan tetapi berpengaruh juga terhadap hilangnya sumber daya alam yang terkandung didalamnya, dan juga berkurangnya area kedaulatan.

\section{Aspek Psikologis}

Kemajuan dan tata kelola yang baik atas suatu pulau perbatasan, akan selalu berdampak langsung terhadap perekonomian daerah yang masyarakat atau penduduk tempati. Masyarakat tidak perlu lagi merasa bergantung terhadap negara tetangga walaupun jaraknya lebih dekat.Didalam pergaulan dunia internasionalpun kita juga akan merasa bangga, mempunyai halaman yang selalu terawat dengan baik sehingga akan menimbulkan image yang positif terhadap identitas suatu bangsa. 


\section{Aspek Keamanan}

Kerjasama yang baik antara pemerintah daerah setempat dengan unsur2 keamanan dalam hal ini TNI dan Polri, akan memberikan efek khusus terhadap keamanan jalur lintas laut, baik dari ancaman teroris dan pembajakan, pencurian sumber kekayaan alam, penyelundupan barang, narkoba dan manusia. Sehingga akan menutup kemungkinan tindak kejahatan di laut, maupun termasuk arogansi negara tetangga.

\section{Aspek Sosial Budaya}

Pengaruh sosial budaya akibat pertukaran barang dan jasa, dan juga keluar masuknya masyarakat demi menunjang siklus perekonomian mau tidak mau akan berdampak langsung terhadap sendi sendi dalam kehidupan bermasyarakat, terutama pulau dan daerah perbatasan sebagai pintu utama wilayah negara. Sisi positif dari pengelolaan daerah yang baik antara lain akan mengurangi ketergantungan masyarakat terhadap pulau yang terdekat (negara tetangga), sehingga diharapkan akan banyak mengurangi dan menutup pengaruh pergeseran sosial budaya, berpotensi merubah identitas asli suatu kawasan, baik itu dalam segi bahasa, maupun kebudayaan.

Dari beberapa aspek tersebut diatas, peran serta pemerintah daerah cukup besar, apalagi kondisi sekarang dalam sistem demokrasi politik multi partai dan pemulihan kepala daerah langsung, kita selalu berharap setiap kepala daerah yang terpilih hendaknya memiliki wawasan nusantara.Kita tentu tidak mengharapkan seorang Kepala Daerah yang hanya mempunyai visi dan misi jangka pendek maupun demi kepentingan partai. Semoga kedepan kita harapkan daerah perbatasan benar-benar dikelola dengan baik oleh pemerintah pusat maupun daerah sehingga dapat berfungsi sebagai halaman yang asri dan selalu terawat dengan baik.

\section{KESIMPULAN}

Belajar dari sejarah, pola pikir pemerintah yang terlalu menganggap remeh dan mengabaikan daerah perbatasan harus segera diubah, perbatasan merupakan halaman depan sebuah kedaulatan, jika halaman depan itu dapat di kelola dengan baik, tentu kedaulatan akan selalu terjaga, dan jika halaman itu selalu diabaikan dan hanya berfungsi sebagai pemenuhan faktor politis, maka besar kemungkinan kasus lepasnya Pulau Sipadan dan Ligitan akan terjadi di kemudian hari.

Perbatasan dan kedaulatan adalah dua kata yang tidak bisa terpisahkan, selama masih ada perhatian yang serius terhadap masalah di perbatasan, maka disitu pula kedaulatan akan selalu terjaga, dan bilamana perbatasan sudah diabaikan maka tinggal menunggu waktu runtuhnya pondasi kedaulatan suatu negara.

\section{DAFTAR PUSTAKA}

Undang-Undang Nomor 17 Tahun 1985 tentang Ratifikasi UNCLOS 1982.

Undang-Undang No. 43 Tahun 2008 tentang Wilayah Negara

Peraturan Presiden Nomor 12 Tahun 2010 tentang pembentukan Badan Pengelolaan Perbatasan

Moeldoko, Letjen TNI, Kompleksitas Pengelolaan Perbatasan, Tinjauan dari Perspektif Kebijakan Pengelolaan Perbatasan Indonesia

Sobar Sutisna, Pengamanan Wilayah Perbatasan Negara Kesatuan Republik Indonesia Dan Kepastian Hukum Bagi Pertahanan Wilayah Negara

Lalu Muhamad Jaelani, Teknik Geodesi Fakultas Teknik Sipil dan Perencanaan, ITS, Sukolilo, Surabaya, 60111

Soerya Respationo, Kebijakan Pertahanan Di Perbatasan Maritim. 